\title{
The avian fossil record in Insular Southeast Asia and its implications for avian biogeography and palaeoecology
}

Excavations and studies of existing collections during the last decades have significantly increased the abundance as well as the diversity of the avian fossil record for Insular Southeast Asia. The avian fossil record covers the Eocene through the Holocene, with the majority of bird fossils Pleistocene in age. Fossil bird skeletal remains represent at least 63 species in 54 genera and 27 families, and two ichnospecies are represented by fossil footprints. Birds of prey, owls and swiftlets are common elements. Extinctions seem to have been few, suggesting continuity of avian lineages since at least the Late Pleistocene, although some shifts in species ranges have occurred in response to climatic change. Similarities between the Late Pleistocene avifaunas of Flores and Java suggest a dispersal route across southern Sundaland. Late Pleistocene assemblages of Niah Cave (Borneo) and Liang Bua (Flores) support the rainforest refugium hypothesis in Southeast Asia as they indicate the persistence of forest cover, at least locally, throughout the Late Pleistocene and Holocene. 


\section{Hanneke J.M. Meijer M,2,3 $^{1}$}

2 Institut Català de Paleontologia Miquel Crusafont, 08193 Cerdanyola del Vallès, Barcelona,

3 Spain. Email: Hanneke.Meijer@icp.cat. Tel: 0034935868338

$4{ }^{2}$ Human Origins Program, National Museum of Natural History, Smithsonian Institution,

5 Washington, DC, USA

$6 \quad{ }^{3}$ Naturalis Biodiversity Center, Leiden, the Netherlands 
8 Ever since the seminal observations of Alfred Russel Wallace $(1863,1869)$, a plethora of

9 studies has highlighted the avian species richness, high levels of endemism, and unique

10 biogeographical patterns, as well as the conservation threats across Insular Southeast Asia (i.e.

11 Huxley, 1868; Mayr, 1944; Butchart et al., 1996: Brooks, Pimm \& Collar, 1997, 1999:

12 Stattersfield et al., 1998; Myers et al., 2000; Trainor \& Lesmana, 2000; Birdlife International,

13 2001; Jones et al., 2001; Jones, Marsden \& Linsley, 2003; Ding et al., 2006; Jønsson et al., 2008,

14 2010; Holt et al., 2013). However, very little is known regarding the evolutionary history of birds

15 in this region. Evidence for extinction events and faunal turnovers in Insular Southeast Asia

16 comes mainly from the mammalian fossil record, particularly proboscideans and primates (i.e.

17 van den Bergh, 1999; Meijaard, 2003; de Vos, van den Hoek Ostende \& van den Bergh, 2007;

18 van der Geer et al., 2010; Louys \& Meijaard, 2010). How past events have shaped current

19 patterns of avian distributions remains unexplored. Here, I provide a synthesis of the current

20 fossil record of birds in Insular Southeast Asia. I describe sites with fossil avian remains, interpret

21 the fossil evidence in terms of avian biogeography and dispersal, and discuss the significance of

22 avian assemblages for Southeast Asian palaeoecology.

\section{MATERIAL AND METHODS}

24 Data on fossil occurrences of avian taxa in Insular Southeast Asia were acquired through

25 the database www.Fossilworks.org (search terms 'Aves' and 'Asia'), from published accounts, and

26 from my own observations. Insular Southeast Asia is defined as the islands in the archipelagos of

27 Indonesia, the Philippines, Malaysia, Singapore, Brunei, East Timor, and Christmas Island.

\section{Localities with avian remains in Insular Southeast Asia}


Although Australia and Asia have both yielded extraordinary fossil bird remains (for an

30 overview, see Murray and Vickers-Rich (2004) and Chiappe (2007)), some of them dating back

31 well into the Cretaceous and including some of the world's earliest birds (Vickers-Rich, 1991;

32 Chiappe, 2007; Martin et al., 2013), fossil bird remains from the island archipelagos in between

33 these continental landmasses are rare. There are no Mesozoic bird remains, which can be

34 attributed to the fact that the majority of islands didn't constitute dry land until the Cenozoic

35 (Hall, 2002).

\section{Sumatra}

The oldest bird remains from Insular Southeast Asia are represented by an almost complete skeleton of the pelecaniform Protoplotus beauforti Lambrecht, 1931 from Sibang in the Sangkarewang Formation, West Sumatra (Fig. 1). The age of the sediments has been disputed, but they are thought to be at least of Eocene age (van Tets, Rich \& Marino-Hadiwardoyo, 1989). Avian footprints have been described from the Oligocene Sawahlunto Formation near Kandi in West Sumatra. These footprints are attributed to two distinct ichnospecies of Aquatilavipes, A.

43 wallacei Zonneveld et al., 2011 and Aquatilavipes sp. A (Zaim et al., 2011, Zonneveld et al., 442011,2012 ), and are most similar to tracks produced by small shorebirds such as sandpipers, rails 45 and plovers (Zonneveld et al., 2011).

\section{Java}

47 Weesie (1982) described avian remains collected from the Middle Pleistocene site of 48 Trinil HaubtKnochen (HK), the type locality for Homo erectus (Dubois, 1893), and from Sumber

49 Kepuh, a locality that is considered to be contemporaneous with H. erectus (Storm, 2012). Weesie 50 (1982) ascribes the fossils from Trinil HK to the greater adjutant Leptoptilos cf. dubius (Gmelin, 
51 1798), black-necked stork Ephippiorhynchus cf. asiaticus (Latham, 1790), the red-breasted goose

52 Branta cf. ruficollis (Pallas, 1769), and the Australian shelduck Tadorna tadornoides (Jardine \&

53 Selby, 1828) and the single fossil from Sumber Kepuh to the green peafowl Pavo m. muticus

54 Linnaeus, 1766 (Supplementary table 1).

55 Alexander Wetmore (1940) described bird bones from bone-bearing terraces near

56 Watualang, situated near the Solo River in central Java (Fig. 1). These terraces are considered to

57 be Late Pleistocene of age and identical with the Ngandong terraces. The bones represented two

58 fossil bird species: a crane, Grus grus (Linnaeus, 1758) and a new species of giant stork,

59 Leptoptilos titan Wetmore, 1940. Wetmore (1940) also tentatively mentions remains of an extinct

60 vulture of the subfamily Aegypinae, but the whereabouts of these fossils is unknown. Bird

61 remains have also been reported from Wajak Cave, East Java (van den Brink, 1982). The bones

62 are ascribed to an owl, Strigiformes indet., and a songbird, Passeriformes indet. The ages

63 suggested for Wajak have ranged from Pleistocene to Holocene, but Storm et al. (2012) found

64 that at least part of the assemblage is Late Pleistocene in age.

\section{Philippines}

66 Reis \& Garong (2001) reported on an Early Holocene terrestrial vertebrate assemblage

67 excavated in four caves in Quezon Municipality on Palawan. Thirty-five bones were identified as

68 avian, and could be assigned to twelve avian taxa (Supplementary table 1); a species of scops

69 owl, Otus sp., three species of swiftlets in the genus Collocalia Gray, 1840 (note that $C$.

70 salangana (Streubel, 1848) is here treated as Aerodramus salanganus following Chantler et al.,

71 1999), and eight species of passerine birds.

\section{Borneo}

73 Stimpson $(2009,2010,2013)$ described fossil bird assemblages associated with human 
74 settlements from the Late Pleistocene and Holocene sediments of Great Cave of Niah in Sarawak,

75 North-western Borneo. He identified 28 taxa (Supplementary table 1) in 8 families, including

76 raptors (Accipitridae) and owls (Strigidae), hornbills (Bucerotidae), and swiftlets (Apodidae).

77 Flores

78 Late Pleistocene and Holocene bird remains from Liang Bua, a limestone cave on the

79 western part of the island, were described by Meijer \& Due (2010) and Meijer et al. (2013). The

80 Liang Bua fossil bird assemblage is diverse and contains at least 25 non-passerine taxa in 14

81 families (Supplementary table 1), including a giant marabou stork Leptoptilos robustus Meijer

82 and Due, 2010, a vulture Trigonoceps sp., owls, pigeons (Columbidae), parrots (Psittacidae) and

83 swiftlets (Apodidae).

84 Other sites

85 Bird remains have been documented for Madai Cave on Sabah (Harrison, 1998) and

86 Early/Middle Pleistocene sites in the Soa Basin of Central Flores (Brumm et al., 2006) but these

87 remains have not been identified yet.

\section{The fossil bird record in Insular Southeast Asia}

To date, sixty-three species of fossil birds have been identified in Insular Southeast Asia,

90 representing at least 54 genera and 27 families (Supplementary table 1). Two taxa are represented

91 by fossil footprints only. While the avian fossil record covers the Eocene through to the

92 Holocene, the majority of fossil avians come from Quaternary sediments. Raptors, owls, and

93 swiftlets are present and abundant in all cave sites excavated, and remain ubiquitous elements in

94 the modern Southeast Asian avifauna today. The current fossil record for birds forms a 
95 significant extension of the last overview of Southeast Asian fossil birds (Rich et al., 1986),

96 which only listed a record for Java. The recent expansion reflects both renewed interest in

97 existing collections (Borneo) as well as new excavation efforts on Sumatra, Flores and Palawan.

98 It is important to note the differences in taphonomy between some of the sites. Open-air

99 sites in fluvial deposits, such as the localities of Watualang and Trinil, are less likely to preserve

100 microfauna, whereas the cave sites on Borneo, Palawan and Flores are more favourable for the

101 preservation of smaller bones. Bone accumulations in caves may result from fluvial transport,

102 pitfalls, burrow deaths, predation and hibernation/aestivation (Andrews, 1990). For Niah Caves,

103 deposition of swiftlets likely resulted from natural death, as the caves have sustained populations

104 of swiftlets for at least 48,000 years (Stimpson, 2013). At Liang Bua (Flores), signs of digestions

105 on the bone surfaces suggest that birds of prey, most likely a species of barn owl (Tyto sp.), are

106 responsible for the accumulation of the majority of non-predatory birds (Meijer et al., 2013).

107 Although many bird bones have been found in association with hominid (Java, Flores) or modern

108 human (Borneo and Palawan) remains, no cut marks or other signs indicative of human hunting

109 have been reported for any bird bones, in contrast to the remains of the pygmy elephant Stegodon

110 florensis insularis van den Bergh et al., 2008 (Van den Bergh et al., 2009).

\section{DISCUSSION}

\section{Avian biogeography}

113 Avian dispersal patterns in Insular Southeast Asia are complex (Jønsson et al., 2008,

114 2010; Carstensen \& Olesen, 2009; Michaux, 2010), as the geological history of the region is

115 complicated (Hall, 2002) and the avifauna contains elements of both Indo-Malayan and

116 Australasian origin (Mayr, 1944; Michaux, 2010). Especially for the Philippines (minus Palawan) 
117 and Wallacea, the use of land bridges to explain inter-island faunal similarities is limited, as these

118 archipelagos were never connected to mainland Asia or Australia. The deep sea-straits between

119 islands formed a dispersal barrier for terrestrial animals, and although birds are generally less

120 hindered by such barriers, the extent to which sea straits affected avian dispersal and

121 diversification in Insular Southeast Asia is poorly understood (Hosner, Nyári \& Moyle, 2013).

122 Molecular studies suggest complex patterns of mainland-island interchange and diversification

123 for passerines (Cumings Outlaw \& Voelker, 2008; Jønsson et al., 2010, 2011), but little work has

124 been done for non-passerine birds (Birks \& Edwards, 2002). Fossil occurrences can provide

125 calibration points for dispersal models based on molecular data, and can reveal past dispersal

126 routes and events that may go unnoticed when only extant taxa are considered.

127 With the exception of the extinct giant storks from Flores and Java (Supplementary table 1),

128 species recorded in fossil assemblages are extant species, suggesting continuity of avian lineages

129 across Southeast Asia since at least the Late Pleistocene. A contraction in species range does

130 seem to have occurred for a number of species. The greater adjutant and the red-breasted goose

131 from the Middle Pleistocene of Java are currently restricted to more northern regions. The

132 Australian shelduck and the black-necked stork are nowadays occasional visitors, and Weesie

133 (1982) considers their presence in Middle Pleistocene Java as indicative of cooler climatic

134 conditions. Whereas the Middle Pleistocene mammal fauna from Java went extinct at the

135 transition to the Late Pleistocene (de Vos, van den Hoek Ostende \& van den Bergh, 2007; van der

136 Geer et al., 2010), birds might have responded by a range shift rather than extinction. On

137 Palawan, the mountain white-eye (Zosterops montanus Bonaparte, 1850) now occurs at higher

138 elevations and seems to have undergone a recent range contraction (Reis \& Garong, 2001). The

139 presence of vultures in Late Pleistocene Insular Southeast Asia is significant, as they are

140 conspicuously absent from the modern avifauna (Thiollay, 1998). Remains of the white-headed

141 vulture Trigonoceps sp. were recovered from Late Pleistocene sediments at Liang Bua (Flores) 
142 (Meijer et al., 2013). Wetmore (1940) reported on two bones from Late Pleistocene sediments at

143 Watualang (Java) "being from a species about the size of Pseudogyps bengalensis. These are

144 typical in form of birds of this group and apparently represent an extinct species." (Wetmore,

145 1940, p. 450) Unfortunately, the whereabouts of these bones remains unclear and their vulturine

146 nature cannot be confirmed at present. The presence of vultures on Flores, and possibly on Java,

147 indicates that the ranges of extant genera of vultures, even those with current distributions limited

148 to Africa, may have been much larger in the past, a conclusion also supported by the presence of

149 two African vulture genera in the middle Pleistocene of China (Zhang et al., 2012). According to

150 Thiollay (1998), the lack of vultures in the modern avifauna results from the lack of mammalian

151 carcasses on islands. Alternatively, species impoverishment, and with that the lack of certain

152 species, along the continent-island gradient can results from nestedness, in which only the

153 abundant, generalist and forest species make up the poorer, island species subset. Avifaunas

154 within Southeast Asia indeed show a high level of nestedness (Carstensen \& Olesen, 2009), but

155 with evidence for fossil vultures in Southeast Asia, nestedness does not explain the modern

156 absence of vultures. The disappearance of Trigonoceps sp. from the Liang Bua sequence at the

157 end of the Late Pleistocene seems to be tied to the disappearance of Homo floresiensis Brown et

158 al., 2004 and Stegodon florensis insularis (Meijer et al., 2013), which left the island devoid of

159 large mammals. Also, both the extant as well as the fossil Javan fauna contains a number of large

160 mammals, including large bovids and deer (and until recently, proboscideans and rhinos as well),

161 which could have provided potential food resources for vultures. The current absence of vultures

162 in insular Southeast Asia seems to be an effect of Late Pleistocene extinction events rather than

163 nestedness.

\section{Avian dispersal routes}


For the Lesser Sunda Islands, different dispersal scenarios have been proposed.

166 Stresemann (1939) suggested that certain terrestrial birds colonized the Sunda Islands from the

167 north (Sulawesi), but others have argued for a route via Southeastern Sundaland based on the

168 similarities between the extant avifaunas of Flores, Java and Bali (Mayr, 1944; Mees, 2006).

169 Such a route agrees with the presence of giant storks in the Late Pleistocene of both Java and

170 Flores, as their large size might represent an adaptation to a more terrestrial life style (though it

171 should be noted here that L. robustus from Flores displays wing morphology similar to modern $L$.

172 dubius, Meijer and Due, 2010). Both the Javan and Flores giant stork may represent late

173 offshoots of the lineage that also contains L. falconeri (Milne-Edwards, 1868) from the Siwalik

174 Hills in India (Louchart et al., 2005). Living Ciconidae display significant sexual dimorphism

175 (Louchart et al., 2005), but Weesie (1892) does not consider the possibility that the stork remains

176 from the Middle Pleistocene of Java (which he attributed to the modern black-necked stork

177 Ephippiorhynchus cf. asiaticus and the greater adjutant L. cf. dubius) might, in fact, be smaller

178 (female) specimens of the giant stork L. titan.

179 Although most of the Sunda Shelf was dry land at some point during the Pleistocene

180 (Hall, 2002), there is no unambiguous geological evidence that Palawan was once connected to

181 Sundaland (see discussion in Reis \& Garong, 2001). Fossil and modern faunal data suggest that

182 Palawan might have been a stepping stone between Borneo and the Philippines. In that light, the

183 fossil presence of the mossy-nest swiftlet Aerodramus cf. salanganus in the very early Holocene

184 is interesting, since it is currently absent on Palawan, but present in the Greater Sundas as well as

185 in the Philippines. Its presence in the early Holocene could indicate that Palawan served as a

186 stepping-stone for the dispersal of A. salanganus from the Greater Sundas into the Philippines.

187 Palaeoecological implications 

much debate. Heaney (1991) proposed the presence of a continuous savannah corridor during

190 glacial maxima, which stretched from the Malaysian Peninsula through central Sundaland all the

191 way to the Lesser Sunda Islands. This savannah corridor presumably facilitated the dispersal of

192 hominins and other terrestrial megafauna across Sundaland, and acted as a dispersal barrier for

193 forest-dependent taxa between Sumatra and Borneo. Although geomorphological,

194 biogeographical, and palynological evidence, as well as vegetation modelling indicate that drier 195 conditions prevailed over Insular Southeast Asia during the Last Glacial Period (for a review, see 196 Bird, Taylor \& Hunt, 2005), there is only very limited support for a continuous savannah corridor 197 at the scale proposed by Heaney (1991). The savannah corridor hypothesis is based on the 198 climatic conditions that occurred during glacial maxima, a situation that existed only for short 199 periods of time during the Pleistocene (Voris, 2000). Furthermore, Slik et al. (2011) argue that the 200 biogeographic difference between Sumatra and the Malay Peninsula, and Borneo can also be 201 explained by exposed sandy sea-bed soils that acted as a dispersal barrier. Instead of savannah 202 vegetation, swamps and heath forest dominated central Sundaland. Birds are closely associated with vegetation, and their abundance and diversity in fossil 204 assemblages adds valuable palaeoecological insights. The habitat spectrum inferred from Liang 205 Bua's avifauna (Meijer et al., 2013) shows that, during the Late Pleistocene, forest habitats, as 206 well as wetland and open grassland habitats dominated around Liang Bua, and provided ample 207 resources for hominins. Studies of the fossil bird assemblage from Niah Cave on Borneo 208 (Stimpson, 2010, 2013) showed that swiftlets, obligate insectivores, had been persistently present 209 from well into the Late Pleistocene until today (Stimpson, 2013). Their continuous presence 210 indicates that habitats within the feeding range of these birds supported a sufficient base of aerial 211 arthropods to support swiftlet populations. Despite ample evidence for drier conditions based on 212 geomorphological, palynological, biogeographical data and climate modelling (see references in 
213 i.e. Bird, Taylor \& Hunt, 2005; Westaway et al 2009), and the concomitant contraction of forests,

214 Late Pleistocene fossil bird assemblages from both Flores and Borneo suggest that forests

215 persisted at least locally. These findings are consistent with other lines of evidence (Cannon,

216 Morley \& Bush, 2009; Wurster et al., 2010; Stimpson, 2012) that suggest that forest habitats were

217 maintained across Insular Southeast Asia throughout the Late Pleistocene and Holocene.

\section{CONCLUSION}

The avian fossil record in Insular Southeast Asian has significantly increased in

abundance and diversity over the last decades, and now consists of at least 63 species,

million years, from the Eocene to the Holocene, but most remains have been found in Quaternary

sediments. Swiftlets, birds of prey and owls are present and abundant in all cave sites excavated, and are ubiquitous elements in the modern Southeast Asian avifauna.

Extinctions seem to have been few, as the majority of the species in the fossil record are extant taxa. A number of species have undergone a range shifts and are currently restricted to cooler regions. Similarities between the Late Pleistocene avifaunas of Flores and Java suggest a dispersal route across southern Sundaland. The mossy-nest swiftlet A. salanganus might have dispersed into the Philippines via Palawan. The Late Pleistocene record of forest birds, particularly swiftlets, suggest that the structural diversity of forest habitats was maintained, at

231 least locally, throughout the Late Pleistocene and into the present.

\section{ACKNOWLEDGEMENTS}

233 This paper was inspired by the 2nd Southeast Asian Gateway Evolution Meeting, held March 11-

23415 2013, in Berlin, Germany, and benefitted from discussions with T. Sutikna, R.A. Due, W.E. 
235 Saptomo, H.F. James, M.W. Tocheri, M.J Morwood, G.D. van den Bergh, A. Brumm, M. Spitzer,

236 and C. Stimpson. A.A.E. van der Geer provided helpful feedback on an earlier version of this 237 manuscript.

\section{REFERENCES}

239 Andrews P. 1990. Owls, caves and fossils: predation, preservation and accumulation of small mammal bones in caves, with an analysis of the Pleistocene cave faunas from Westburysub-Mendip, Somerset, UK. Chicago: The University of Chicago Press.

van den Bergh GD. 1999. The late Neogene elephantoid-bearing faunas of Indonesia and their palaeozoogeographic implications: a study of the terrestrial faunal succession of Sulawesi, Flores and Java, including evidence for early hominid dispersal east of Wallace's Line. Scripta Geologica 117:1-419.

van den Bergh GD, Due RA, Morwood MJ, Sutikna T, Jatmiko, Saptomo W. 2008. The youngest Stegodon remains in South-East Asia from the late Pleistocene archaeological site Liang Bua, Flores, Indonesia. In: Palombo MR., ed. Insularity and its Effects. Quaternary International, 182:16-48.

254 Bird MI, Taylor D, Hunt C. 2005. Palaeoenvironments of insular Southeast Asia during the Last 2242.

257 Birdlife International. 2001. Threatened birds of Asia: the BirdLife International Red Data Book. 
Cambridge: BirdLife International (http://www.rdb.or.id).

259

260

261

262

263

264

265

266

267

268

269

270

271

272

273

274

275

276

277

278

279

280

281

282

Birks SM, Edwards SV. 2002. A phylogeny of the megapodes (Aves: Megapodiidae) based on nuclear and mitochondrial DNA sequences. Molecular Phylogenetics and Evolution 23:408-421.

Bonaparte CL. 1850. Conspectus Generum Avium, Volume 1. Leiden: E. J. Brill.

van den Brink LM. 1982. On the mammal fauna of the Wajak Cave, Java (Indonesia). Modern Quaternary Research in Southeast Asia 7:177-193.

Brooks T, Pimm SL, Collar, NJ. 1997. Deforestation predicts the number of threatened birds in Insular Southeast Asia. Conservation Biology 11:382-394.

Brooks TM, Pimm SL, Kapos V, Ravilious C. 1999. Threat from deforestation to montane and lowland birds and mammals in insular South-east Asia. Journal of Animal Ecology 68:1061-1078.

Brown P, Sutikna T, Morwood MJ, Soejono RP, Jatmiko, Saptomo EW, Due RA. 2004. A new small-bodied hominin from the late Pleistocene of Flores, Indonesia. Nature 403:10551061.

Brumm A, Aziz F, van den Bergh GD, Morwood MJ, Moore, MW, Kurniawan I, Hobbs DR, Fullagar R. 2006. Early stone technology on Flores and its implications for Homo floresiensis. Nature 441:624-628.

Butchart SHM, Brooks TM, Davies CWN, Dharmaputra G, Dutson GCL, Lowen JC, Sahu A. 1996. The conservation status of forest birds on Flores and Sumbawa, Indonesia. Bird Conservation International 6:335-370.

Cannon CH, Morley RJ, Bush ABG. 2009. The current refugial rainforests of Sundaland are unrepresentative of their biogeographic past and highly vulnerable to disturbance.

Proceedings of the National Academy of Sciences $\quad$ USA 106:11188-11193.

Carstensen DW, Olesen JM. 2009. Wallacea and its nectarivorous birds: nestedness and 
283 modules. Journal of Biogeography 36:1540-1550.

284 Chantler P, Wells DR, Schuchmann KL. 1999. Family Apodidae (Swifts). In: Del Hoyo J, Elliott

285 A, Sargatal J, eds. 1999. Handbook of the Birds of the World. Vol. 5, Barnowls to

286 Hummingbirds. Barcelona: Lynx Editions, 388-457.

287 Chiappe LM. 2007. Glorified Dinosaurs: The Origin and Early Evolution of Birds.

288 Hoboken: Wiley-Liss, Hoboken.

289 Cumings Outlaw D, Voelker G. 2008. Pliocene climatic change in insular Southeast Asia as

290 an engine of diversification in Fidecula flycatchers. Journal of Biogeography 35:739-752.

291 Dubois MEFT. 1893. Paleontologische Onderzoekingen op Java. Extra bijvoegsel der Javasche

292 Courant, Verslag van het Mijnwezen over het 3e kwartaal 1892, 10-14.

293 Ding T-S, Yuan H-W, Geng S, Koh C-N, Lee P-F. 2006. Macro-scale bird species richness

294 patterns of the East Asian mainland and islands: energy, area and isolation. Journal of

295 Biogeography 33:683-693.

296 Van der Geer AAE, Lyras G, de Vos J, Dermitzakis M. 2010. Evolution of island mammals:

297 adaptation and extinction of placental mammals on islands. Sussex: Wiley-Blackwell.

298 Gray GR. 1840. A List of the Genera of Birds, with an Indication of the Typical Species of

299 Each Genus, Volume 1. London: Richard and John E. Taylor.

300 Gmelin JF. 1789. Systema naturae, per regna tria naturae, secundum classes, ordines,

301 genera, species, cum characteribus, differentiis, synonymis, locis, 13th edn. Leipzig: G.E.Beer.

302 Hall R. 2002. Cenozoic geological and plate tectonic evolution of SE Asia and the SW

303 Pacific: computer-based reconstructions, model and animations. Journal of Asian Earth

304 Sciences 20:353-431.

305 Harrison T. 1998. Vertebrate faunal remains from Madai Cave (MAD 1/28), Sabah, East

306 Malaysia. Bulletin Indo-Pacific Prehistory Association 17:85-92.

307 Heaney LR. 1991. A synopsis of climatic and vegetational change in southeast Asia. 
309 Holt BG, Lessard J-P, Borregaard MK, Fritz MK, Araújo MB, Dimitrov D, Fabre P- $\quad$ H,

310 Graham CH, Graves GR, Jønsson KA, Nogués-Bravo D, Wang Z, Whittaker RJ, Fjeldså J,

311 Rahbek C. 2013. An Update of Wallace's Zoogeographic Regions of the World. Science

312 339:74-78.

313 Hosner PA, Nyári ÁS, Moyle RG. 2013. Water barriers and intra-island isolation contribute to

314 diversification in the insular Aethopyga sunbirds (Aves: Nectariniidae). Journal of

315 Biogeography 40:1094-1106.

316 Huxley T. 1868. On the Classification and Distribution of the Alectoromorphae and

317 Heteromorphae, Proceedings of the Zoological Society of London 294-319.

318 Jardine W, Selby PJ. 1828. Illustrations of Ornithology, Volume 1. Edinburgh: WH Lizars.

319 Jones MJ, Sullivan MS, Marsden SJ, Linsley MD. 2001. Correlates of extinction risk of birds

320 from two Indonesian islands. Biological Journal of the Linnean Society 73:65-79.

321 Jones MJ, Marsden SJ, Linsley MD. 2003. Effects of habitat change and geographical

322 variation on the bird communities of two Indonesian islands. Biodiversity and

323 Conservation 12:1013-1032.

324 Jønsson KA, Irestedt M, Fuchs J, Ericson PGP, Christidis L, Bowie RCK, Norman JA,

325 Pasquet E, Fjeldså J. 2008. Explosive avian radiations and multi- directional dispersal across

326 Wallacea: evidence from the Campephagidae and other Crown Corvida (Aves). Molecular

327 Phylogenetics and Evolution 47: $\quad$ 221-236.

328 Jønsson KA, Bowie RCK, Moyle RG, Christidis L, Norman JA, Benz BW, Fjeldså J. 2010.

329 Historical biogeography of an Indo-Pacific passerine bird family (Pachycephalidae):

330 different colonization patterns in the Indonesian and Melanesian archipelagos. Journal of

331 Biogeography 37:245-257.

332 Lambrecht K. 1931. Protoplotus beauforti n.g. n.sp., ein Schlangenhalsvogel aus dem Tertiär 
334 Nederlandisch-Indie 17:15-24.

335 Latham J. 1790. Index ornithologicus, sive systema ornithologiae complectens avium

336 divisionem in classes, ordines, genera, species, ipsarumque varietates: adjectis

337 synonymis, locis, descriptionibus. London: Leigh \& Sotheby.

338 Linnaeus C. 1758. Systema naturae per regna tria naturae, secundum classes, ordines,

339 genera, species, cum characteribus, differentiis, synonymis, locis. Tenth edition. Stockholm,

340 Laurentii Salvii.

341 Linnaeus C. 1766. Systema naturae per regna tria naturae, secundum classes, ordines,

342 genera, species, cum characteribus, differentiis, synonymis, locis. Tomus I. Twelfth edition.

343 Stockholm, Laurentii Salvii.

344 Louchart A, Vignaud P, Likius A, Brunet M, White TD. 2005. A large extinct marabou stork

345 in African Pliocene hominid sites, and a review of the fossil species of Leptoptilos. Acta

346 Palaeontologica Polonica 50:549-563.

347 Louys J, Meijaard, E. 2010. Palaeoecology of Southeast Asian megafauna-bearing sites

348 from the Pleistocene and a review of environmental changes in the region. Journal of

349 Biogeography 37:1432-1449.

350 Martin AJ, Vickers-Rich P, Rich TH, Hall M. 2013. Oldest known avian footprints from

351 Australia: Eumeralla Formation (Albian), Dinosaur Cove, Victoria. $\quad$ Palaeontology, doi:

$35210.1111 /$ pala.12082.

353 Mayr E. 1944. Wallace's Line in the light of recent zoogeographic studies. Quarterly Review of

354 Biology 19:1-14.

355 Mees GF. 2006. The avifauna of Flores (Lesser Sunda Islands). Zoologische Mededelingen

$356 \quad$ Leiden 80:1-261.

357 Meijaard E. 2003. Mammals of south-east Asian islands and their Late Pleistocene 
environments. Journal of Biogeography 30:1245-1257.

359 Meijer HJM, Due RA. 2010. A new species of giant marabou (Aves: Ciconiiformes) from

360 the Pleistocene of Liang Bua, Flores (Indonesia). Zoological Journal of the Linnean Society

$361 \quad 160: 707-724$.

362 Meijer HJM, Sutikna T, Saptomo WE, Due RA, Wasisto S, James HF, Morwood MJ, Tocheri

363 MW. 2013. Late Pleistocene-Holocene non-Passerine Avifauna of Liang Bua (Flores,

364 Indonesia). Journal of Vertebrate Paleontology 33:877- 894.

365 Michaux B. 2010. Biogeology of Wallacea: geotectonic models, areas of endemism, and

366 natural biogeographical units. Biological Journal of the Linnean Society 101:193-212.

367 Milne-Edwards A. 1867-71. Recherches anatomiques et paléontologiques pour server à

368 l'histoire des oiseaux fossiles de la France, Vol. II. Paris: E. Martinet.

369 Murray PF, Vickers-Rich P. 2004. Magnificent mihirungs: the colossal flightless birds of the

370 Australian dreamtime. Bloomington: Indiana University Press.

371 Myers N, Mittermeier RA, Mittermeier CG, da Fonseca GAB, Kent J. 2000. Biodiversity

372 hotspots for conservation priorities. Nature 403:853-858.

373 Pallas PS. 1769. Spicilegia zoologica quibus novae imprimis et obscurae animalium species

374 iconibus, descriptionibus atque commentariis illustrantur. Fasciculus sextus. Berlin: G. A.

375 Lange.

376 Reis KR, Garong AM. 2001. Late Quaternary terrestrial vertebrates from Palawan Island,

377 Philippines. Palaeogeography, Palaeoclimatology, Palaeoecology 171:409-421.

378 Rich PV, Hou LH, Ono K, Baird RF. 1986. A review of the fossil birds of China, Japan and

379 Southeast Asia. Geobios 19:755-772.

380 Slik FJW, Aiba S-I, Bastian M, Brearley FQ, Cannon CH, Eichhorn KAO, Fredriksson G,

381 Kartawinata K, Laumonier Y, Mansor A, Marjokorpi A, Meijaard E, Morley RJ, Nagamasu H,

382 Nilus R, Nurtjahya E, Payne J, Permana A, Poulsen AD, Raes N, Riswan S, van Schaik CP, 
383 Sheil D, Sidiyasa K, Suzuki E, van Valkenburg JLCH, Webb CO, Wich V, Yoneda T, Zakaria R, 384 Zweifel N. 2011. Soils on exposed Sunda Shelf shaped biogeographic patterns in the 385 equatorial forests of Southeast Asia. Proceedings of the National Academy of Sciences USA 386 108:12343-12347.

387 Stattersfield AJ, Crosby MJ, Long AJ, Wege DC. 1998. Endemic Bird Areas of the world: 388 priorities for biodiversity conservation. Cambridge: BirdLife International.

389 Stimpson CM. 2009. Raptor and Owl Bone from Niah Caves, Sarawak: Identifications and 390 Morphological Variation in the Humerus and Tarsometatarsus of Selected Raptors.

391 International Journal of Osteoarchaeology 19:476-490.

392 Stimpson CM. 2010. Late Quaternary Environments and Human Impact in North-western

393 Borneo: the evidence from the bird (Aves) and bat (Mammalia: Chiroptera) faunas from the

394 archaeology of the Great Cave of Niah, Sarawak. PhD Thesis, University of Cambridge.

395 Stimpson, CM. 2012. Local-scale, proxy evidence for the presence of closed canopy forest

396 in North-western Borneo in the late Pleistocene: bones of Strategy I bats from the

397 archaeological record of the Great Cave of Niah, Sarawak. Palaeogeography,

398 Palaeoclimatology, Palaeoecology 331:136-149.

399 Stimpson CM. 2013. A 48,000 year record of swiftlets (Aves: Apodidae) in North- western

400 Borneo: Morphometric identifications and palaeoenvironmental implications.

401 Palaeogeography, Palaeoclimatology, Palaeoecology 374:132- 143.

402 Storm P. 2012. A carnivorous niche for Java Man? A preliminary consideration of the abundance 403 of fossils in Middle Pleistocene Java. Comptes Rendus Palevol 11:191-202.

404 Storm P, Wood R, Stringer C, Bartsiokas A, de Vos J, Aubert M, Kinsley L, Grun R. 2012.

405 U-series and radiocarbon analyses of human and faunal remains from Wajak, Indonesia.

406 Journal of Human Evolution 64:356-365.

407 Stresemann E. 1939. Die Vögel von Celebes. Zoogeographie. Journal of Ornithologie 87:312- 
409 Streubel AV. 1848. Die Cypseliden der Berliner Museums. Isis von Oken 5:348-373.

410 Thiollay J-M. 1998. Distribution patterns and insular biogeography of South Asian raptor 411 communities. Journal of Biogeography 25:57-72.

412 Trainor C, Lesmana D. 2000. Exploding volcanoes, unique birds, gigantic rats and elegant 413 ikat: identifying sites of international conservation significance on Flores, East Nusa Tenggara.

414 Bogor: PKA/BirdLife International/WWF.

415 Van Tets GF, Rich PV, Marino-Hadiwardoyo HR. 1989. A reappraisal of Protoplotus 416 beauforti from the early Tertiary of Sumatra and the basis of a new pelecaniform family.

417 Bulletin of the Geological Research and Development Centre, Paleontology Series 5:57-75.

418 Vickers-Rich P. 1991. The Mesozoic and Tertiary history of birds on the Australian plate. 419 In: Vickers-Rich P, Monaghan JM, Baird RF, Rich TH, eds. Vertebrate Palaeontology of 420 Australasia. Melbourne: Pioneer Design Studio in cooperation with the Monash University 421 Publications Committee, 722-808.

422 Voris HK. 2000. Maps of Pleistocene sea levels in South East Asia: shorelines, river $423 \quad$ systems, time durations. Journal of Biogeography 27:1153-1167.

424 de Vos J, van den Hoek Ostende LW, van den Bergh GD. 2007. Patterns in insular evolution of 425 mammals: a key to island palaeogeography. In: Renema W, ed. Biogeography, time, and 426 place: distributions, barriers, and islands. $\quad$ Dordrecth: Springer, 315-345.

427 Wallace AR. 1863. On the Physical Geography of the Malay Archipelago. Journal of the 428 Royal Geographical Society 33:217-234.

429 Wallace AR. 1869. The Malay Archipelago. London: Macmillan and Company.

430 Weesie PDM. 1982. The fossil bird remains in the Dubois collection. Modern Quaternary 431 Research in Southeast Asia 7:87-90.

432 Westaway KE, Roberts RG, Sutikna T, Morwood MJ, Drysdale R, Zhao J-x, Chivas

AR. 
2009. The evolving landscape and climate of western Flores: an environmental context for the

434 archaeological site of Liang Bua. Journal of Human Evolution 57:450-464.

435 Wetmore A. 1940. Avian remains from the Pleistocene of Central Java. Journal of Paleontology $436 \quad 14: 447-450$.

437 Wurster CM, Bird MI, Bull ID, Creed F, Bryant C, Dungait JAJ, Paz V. 2010. Forest

438 contraction in north equatorial Southeast Asia during the Last Glacial Period.

439 Proceedings of the National Academy of Sciences USA 107:15508-15511.

440 Zaim Y, Yan R, Gunnell GF, Stidham TA, Ciochan RL, Aswan. 2011. First evidence of

441 Miocene avian tracks from Sumatra. Berita Sedimentologi 20:5-6.

442 Zhang Z, Huang Y, James HF, Hou L. 2012. Two Old World vultures from the middle

443 Pleistocene of northeastern China and their implications for interspecific competition and

444 biogeography of Aegypiinae. Journal of Vertebrate Paleontology 32:117-124.

445 Zonneveld J-P, Zaim Y, Rizal Y, Ciochan RL, Bettis III EA, Aswan, Gunnell GF. 2011.

446 Oligocene shorebird footprints, Kandi, Ombilin Basin, Sumatra. Ichnos. An International

447 Journal for Plant and Animal Traces 18:221-227.

448 Zonneveld J-P, Zaim Y, Rizal Y, Ciochan RL, Bettis III EA, Aswan, Gunnell GF. 2012.

449 Ichnological constraints on the depositional environment of the Sawahlunto Formation,

450 Kandi, northwest Ombilin Basin, west Sumatra, Indonesia. Journal of Asian Earth Sciences

$451 \quad 45: 106-113$.

\section{FIGURE CAPTIONS}

453 Figure 1. Map of Insular Southeast Asia indicating the location of localities with fossil bird 454 remains. 
455 Supplementary Table 1. Fossil bird species from Insular Southeast Asia. $\dagger$ indicates an extinct 456 species; $(\dagger)$ indicates a possibly extinct species; * indicates a species that is no longer 457 present in Insular Southeast Asia. 


\section{Figure 1}

Map of Insular Southeast Asia indicating the location of localities with fossil bird remains.

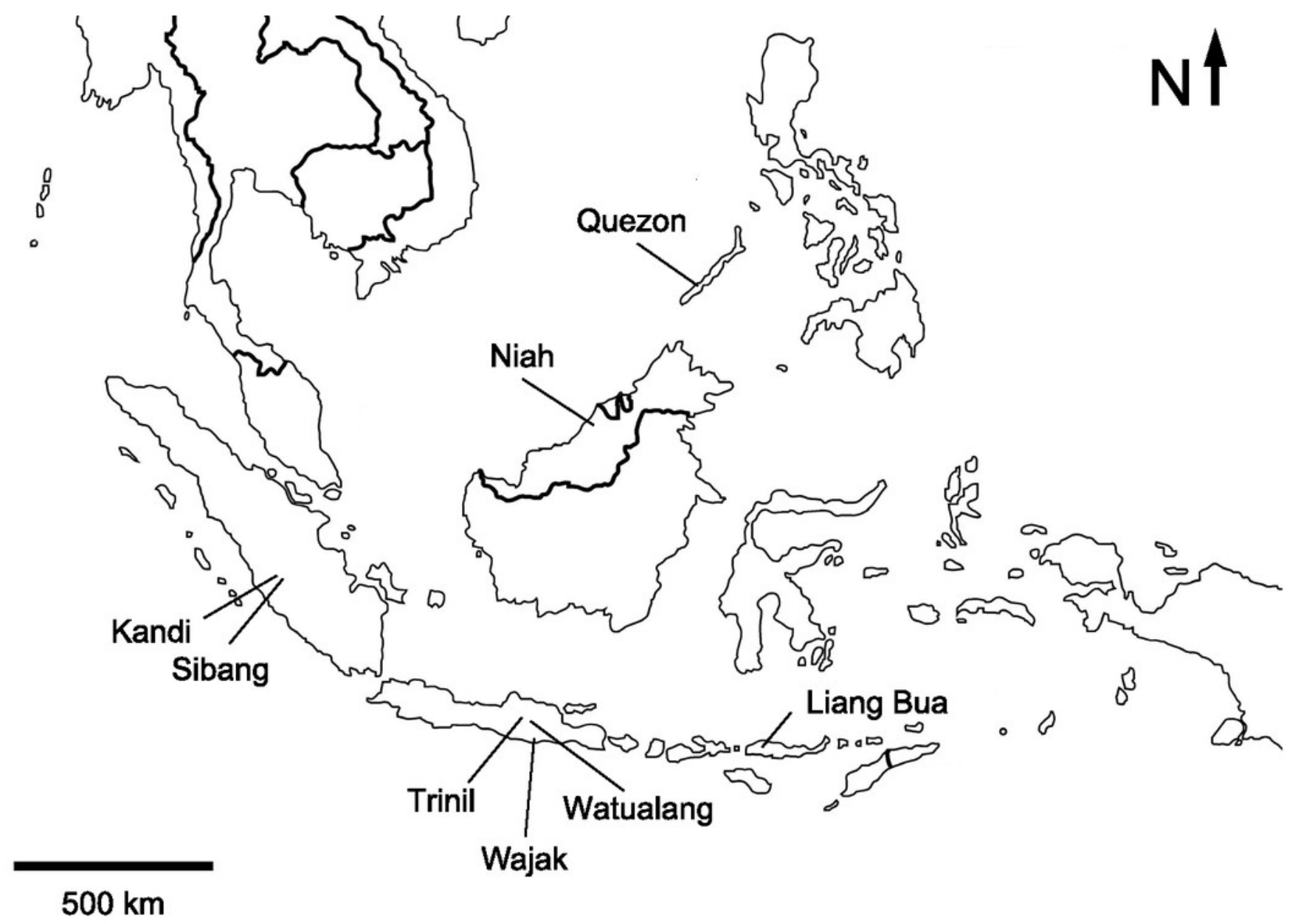

